\title{
Factors Considered for Media Planning during Initial Brief Meeting:A Comparative Study on Preference of Ad-Agencies and Their Clients
}

\author{
P.G.Arul \\ Department of International Business, Pondicherry Central University, Pondicherry- 605014, India \\ *Corresponding Author:pgarul@rediffmail.com
}

Copyright (C) 2013 Horizon Research Publishing All rights reserved.

\begin{abstract}
The use of information to support marketing decisions making is increasingly recognized. The majority of the advertising campaigns are built on insufficient and inadequate information. Especially on media planning practices adopts by ad-agencies in delivering the advertisements in media become complicated due to media explosion. The media planners have highlighted the need to utilize information available and held by their clients for effective anticipation and its developments media plan to gain competitive advantage over others. The main purpose of conducting brief meeting is to formally evaluate the current state/progress, growth of brands and its market structure in the light of the brand intention of the clients. If there is difference in perception of information sharing by ad-agencies and clients in the initial stage of media planning will dilute the company objectives which is hoping to achieve through media. The research findings of this paper highlights the brief meeting take place between the ad-agencies and clients can be considered a checklist and guide for the media planner. It always better for the clients to have understanding with ad-agencies in sharing information and consider ad-agencies as partners of their business.
\end{abstract}

Keywords Advertising, Ad-Agency, Clients, Media Planning, Media Brief/Initial Meeting

\section{Introduction}

Media planning is defined as "the process of designing a course of action that shows how advertising time and space will be used to contribute to the achievement of marketing objectives" (Arnold Barban, Stephan M. Cristol and Frank J. Kopec 1995). In carrying out a media-planning programme certain essential steps in advertising planning are followed with regard to advertising objectives, strategies, tactics, and all servicing to define its purpose of advertisement campaign.
Before the media plan is worked out, certain steps are taken to carry out an effective media plan. For that purpose, the ad-agencies and the clients gather information for analysis. On the basis of the information gathered, the analysis is made for sound media selection, audience selection, target market selection, and the message intended to communicate to the target group are decided. "The first step in any media planning is the collection of useful information about the people or the market to be reached through advertising" (Chunawalla, S.A. Sethia K.C.1995)

The various stages through which a media plan evolves in an ad-agency are quite complex. They vary from agency to agency, and within the agency, from account (client) to account (client). The variations depend on the size of the problem to be tackled, agency organisation structure and its relationship with its clients.

\section{Information Perception for Media Planning by Ad-agencies and Clients}

"Planning is critical to the success of any marketing campaign. Those who start with a written plan see faster and stronger growth than those who just market without pleasing because business will be slow for them (Muhamed 2001). The media planners have to gather data and support the media plan before the initial plan is worked out. A well-developed media planning system would need to include data regarding reach and frequency of media vehicles, qualitative characteristics, details regarding alternative communication formats, marketing factors, competitors' communication information and advertising objectives. "The use of information to support marketing decisions making is increasingly recognized. However, this does not seem to have been carried across into the field of advertising. The majority of the advertising campaigns were built on insufficient and inadequate information" (Russell Abratt, Deanna Cowan 1991). Once the media planner begins to rely on human judgment alone, it is too complex. 
That is why the media planners have highlighted the need to utilize information held by their clients for effective anticipation and its developments, accelerates, the creative decision making process, and shortens the advertising horizon in a competitive advantage.

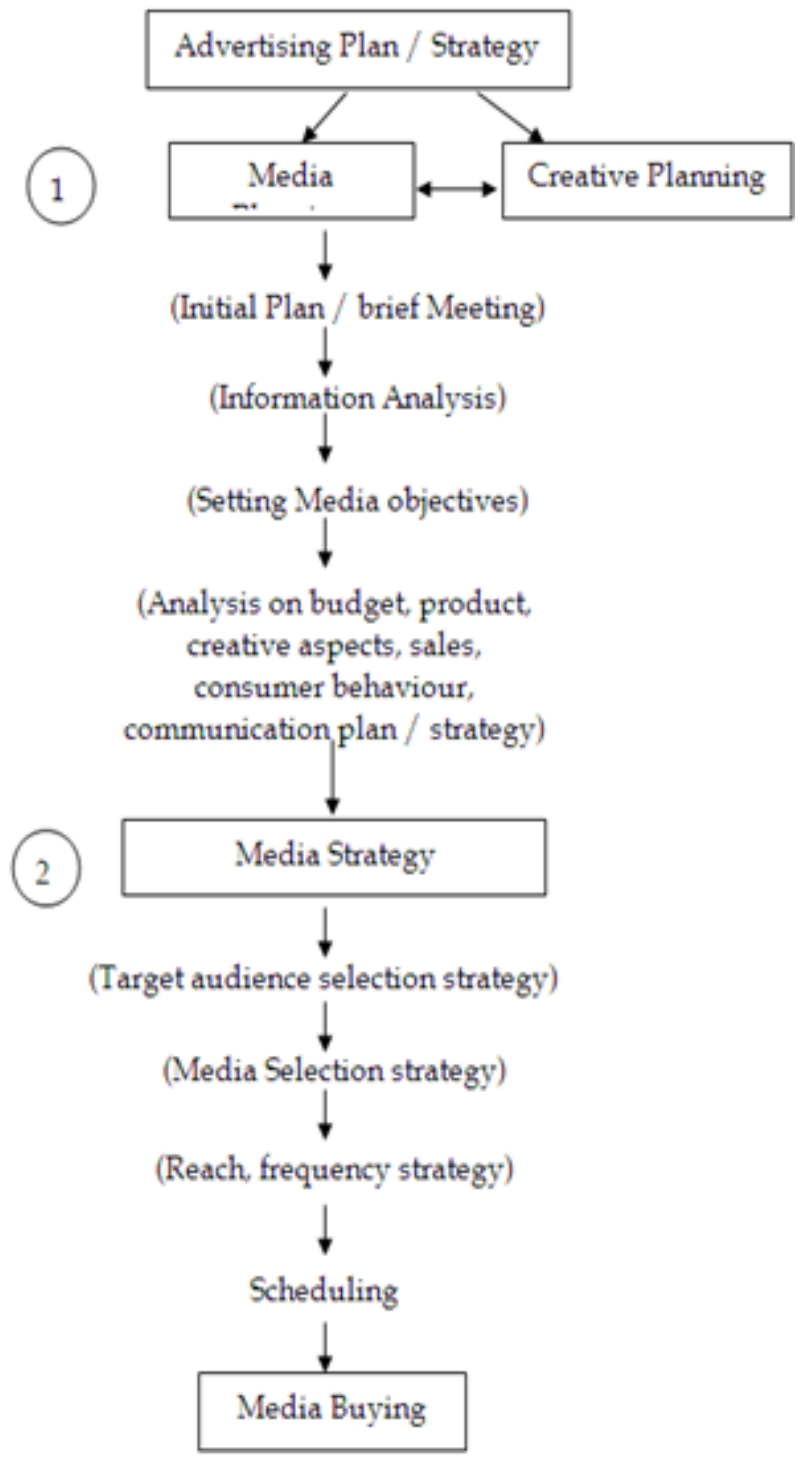

Chart 1:1. Media Planning and Implementation Process

\section{Initial Plan Meeting/Brief Meeting}

The brief meeting of media can be referred to as a checklist for the media planners to help them prepare media plan for a client organization. Media plan is not an isolated function but an integral part of the overall campaign planning. Hence, a media planner is to have thorough knowledge of all variables. With the proliferation in the media and media markets becoming more complex, given the heterogeneity of the target audience, special efforts are made to prepare the media brief meeting. After gathering the information related to market, the media, and audience by the planner and the clients sit together to share their views with each other. The brief meeting or the initial plan meeting is usually a large one. It comprises of senior people of the agency working on the account (clients), the marketing and research executives, the creative and media personnel in the agency to discuss the media related matters along with the clients' representatives in general. The media brief meeting needs to be shared and agreed upon by the planners and the clients. The main purpose of this is to formally evaluate the current state/progress, growth of brand, and its market structure in the light of the brand intention for the period under review.

\section{Objectives of the Study}

1. To study the factors considered during the initial/brief meeting to prepare media planning strategies by ad-agencies and clients

2. To understand the perception of ad-agencies and clients during brief meeting in preparing media planning strategies.

3. To examine the problems encountered by ad-agencies and their clients during initial/brief meeting to prepare media planning strategies.

\section{Hypothesis}

To test the above objectives the following the hypothesis are framed:

1. There is no significant difference between ad-agencies and clients in respect of their ranking sum scores of the issues considered in media initial / brief meeting.

2. There is no significant different between ad-agencies and clients in respect of their rank sum scores of the information need for media planning.

\section{Methodology}

For the purpose of study a detailed interview schedule covering the areas of media planning factors \& strategy, technique of media buying, agency-client relationship, and the problems in media planning and buying was prepared and collected as primary data. To support the information, thus collected as primary data the media executive/director/planner media buyers/executive, account executive were interviewed and the practice followed were ascertained. A structured questionnaire was administered for collection of primary data from clients involving details regarding the agency-client relationship factors, expectation from media planning and buying, agency selection strategy adopted, reason for turnover. The secondary data are collected from the marketing and advertising journals, books, news, letters to support the primary data. Mathematical and statistical tools were used to test the framed hypothesis. To best the information requirement preference given by 
planners and clients for media planning, the factors considered by the national and state level agency planners for media selection, the importance given to competitor's ad-efforts in media planning by national and state level agency media planners, expectation of clients have been tested through student ' $t$ ' test and co-variance analysis for equality of means.

\section{Sample Frame}

For the purpose of study, a stratified random sample of 25 ad-agencies, from as many as 75 actively functioning ad-agencies in Tamil Nadu, has been identified and selected. While selecting the sample the agencies, which are functioning national and state level are given weightage. For cross-section examination of the functioning of these agencies, a sample of 50 clients have been selected from client list furnished by ad-agencies.

\section{Analysis and Interpretation}

Generally the media planners and the clients favour a good media that should ideally include the following issues shown in the Table 1.1 while conducting the initial/brief meeting:

ISSUES CONSIDERED IN MEDIA INITIAL / BRIEF

$$
\text { MEETING }
$$

(A Comparison Between Ad-Agencies and Clients)

Table 1:1. Results of Friedman ANOVA and Kendall's Coefficient of Concordance for Ranking Scores of Ag-Agencies and Clients over 'Issues Taken Into Consideration in Media Initial / Brief Meeting'

\begin{tabular}{|c|c|c|c|c|c|c|c|}
\hline \multirow{2}{*}{$\begin{array}{l}\text { Sl. } \\
\text { No }\end{array}$} & \multirow{2}{*}{ Issues Considered in Media Initial / Brief Meeting } & \multicolumn{3}{|c|}{ Ad-Agencies $(n=25)$} & \multicolumn{3}{|c|}{ Clients $(n=50)$} \\
\hline & & $\begin{array}{c}\text { Average } \\
\text { Rank }\end{array}$ & $\begin{array}{l}\text { Sum of } \\
\text { Ranks }\end{array}$ & $\begin{array}{c}\text { Rank } \\
\text { Obtai-ned }\end{array}$ & $\begin{array}{c}\text { Average } \\
\text { Rank }\end{array}$ & $\begin{array}{l}\text { Sum of } \\
\text { Ranks }\end{array}$ & $\begin{array}{c}\text { Rank } \\
\text { Obtai-ned }\end{array}$ \\
\hline 1 & All Objectives (Corporate advertising media) & 3.18 & 79.5 & 3 & 1.96 & 98.0 & 2 \\
\hline 2 & Target Market & 5.92 & 148.0 & 6 & 4.10 & 205.0 & 4 \\
\hline 3 & Target Audience & 3.66 & 91.5 & 4 & 4.30 & 215.0 & 4 \\
\hline 4 & Media Budget & 1.28 & 32.0 & 1 & 1.60 & 80.0 & 1 \\
\hline 5 & Competitors & 4.64 & 116.0 & 5 & 5.66 & 283.0 & 6 \\
\hline 6 & Media and Its Availability & 7.44 & 186.0 & 7 & 6.84 & 342.0 & 7 \\
\hline 7 & Product / Brand & 2.56 & 64.0 & 3 & 3.90 & 195.0 & 4 \\
\hline 8 & Media Buying & 7.32 & 183.0 & 7 & 7.64 & 382.0 & 8 \\
\hline & Kendall's 'W' (Coefficient of Concordance) & \multicolumn{3}{|c|}{0.8883} & \multicolumn{3}{|c|}{0.8257} \\
\hline & Friedman ANOVA Chi-Square Value & \multicolumn{3}{|c|}{$\begin{array}{c}155.45^{* *} \\
(7\end{array}$} & \multicolumn{3}{|c|}{$\begin{array}{c}288.99 * * \\
(7\end{array}$} \\
\hline
\end{tabular}

**Significant at 1 per cent level.

Figures in brackets shows the degrees of freedom

Table value of Chi-square for d.f. 7 at $5 \%$ level $=14.07$ and at $1 \%$ level $=18.48$ 
Table 1.1 shows the results of Friedman ANOVA and Kendall's 'W'. From the table it can be known that the calculated coefficient of concordance values of 0.8883 and 0.8257 respectively for both ad-agencies and clients in respect of their ranking score are very high and statistically significant as the calculated Friedman ANOVA chi-square values, 155.45 and 288.99 respectively for both ad-agencies and clients are greater than the table value of 18.48 at 1 per cent level of significance for degrees of freedom 7 .

From the above results, it can be inferred that the samples for ad-agencies and clients are drawn from the population with different median ranking values and the high Kendall's coefficient of concordance for both ad-agencies and clients exposed the truth that there is a significant agreement (relatedness) in the ranking of the 'Issues considered in Media Initial / Brief Meeting' measurement items among ad-agencies as well as clients.

\section{Comparison of Ranking Perception of Ad-Agencies and Clients Regarding 'Issues Considered in Media Initial / Brief Meeting'}

Comparison of ranking scores ad-agencies and clients in respect of 'Issues considered in Media Initial / Brief Meeting', are done with a non-parametric 'Mann-Whitney U test' and the results are presented in the table 1.2.

\section{Null Hypothesis}

$\mathrm{H}_{\mathrm{o}}$ :There is no significant difference between Ad-agencies and Clients in respect of their rank sum scores of the 'Issues considered in Media Initial / Brief Meeting'.

Results of ' $U$ ' statistic values revealing the significant level of difference in the rank sum scores of ad-agencies and clients are presented in Table 1:2. The results implies that 'Target Market issues' with ' $U$ ' value of 456.5 (|Z| value = 1.96) is significant at 5 per cent level, and issues related to 'competitors' and 'media and its availability' respectively with ' $U$ ' values of $392.5(|\mathrm{Z}|$ value $=2.71)$ and $396.0(|\mathrm{Z}|$ value $=2.74)$ are significant at 1 per cent level.

All other remaining 5 items except those 3 items have shown insignificant difference between rank sum scores of ad-agencies and clients regarding 'Issues considered in Media Initial / Brief Meeting'. That is, majority of the items ( 5 out of 8 ) have shown insignificant results. The above results lead to the conclusion that there is no significant difference between Ad-agencies and Clients in respect of their rank sum scores of the Issues considered in Media Initial / Brief Meeting. Hence, the null hypothesis is accepted .

Table 1:2. Results of Mann-Whitney 'U' Test Between Rank Sum Scores of Ad-agencies and Clients for 'Issues considered in Media Initial / Brief Meeting' Measurement Items

\begin{tabular}{|c|c|c|c|c|c|}
\hline \multirow{2}{*}{$\begin{array}{l}\text { Sl. } \\
\text { No }\end{array}$} & \multirow{2}{*}{$\begin{array}{l}\text { Issues considered in Media } \\
\text { Initial / Brief Meeting }\end{array}$} & \multicolumn{2}{|c|}{ Rank Sums } & \multirow{2}{*}{$\begin{array}{l}\text { 'U' Test } \\
\text { Value }\end{array}$} & \multirow{2}{*}{$\begin{array}{c}\text { 'Z' } \\
\text { Value }\end{array}$} \\
\hline & & $\begin{array}{l}\text { Ad-Agencies } \\
\quad(\mathrm{n}=25)\end{array}$ & $\begin{array}{l}\text { Clients } \\
(\mathrm{n}=50)\end{array}$ & & \\
\hline 1 & All Objectives & 1753.0 & 1097.0 & 478.0 & -1.70 \\
\hline 2 & Target Market & 1731.5 & 1118.5 & $456.5^{*}$ & -1.96 \\
\hline 3 & Target Audience & 1995.0 & 855.0 & 530.0 & -1.09 \\
\hline 4 & Media Budget & 1898.0 & 952.0 & 623.0 & -0.02 \\
\hline 5 & Competitors & 2132.5 & 717.5 & $392.5^{* *}$ & -2.71 \\
\hline 6 & Media and Its Availability & 1671.0 & 1179.0 & $396.0 * *$ & -2.74 \\
\hline 7 & Product / Brand & 1969.0 & 881.0 & 556.0 & -0.79 \\
\hline 8 & Media Buying & 1963.0 & 887.0 & 562.0 & -0.77 \\
\hline
\end{tabular}

*Significant at 5 per cent level; **Significant at 1 per cent level.

Table value of $\mathrm{Z}$ at $5 \%$ level $=1.96$ and at $1 \%$ level $=2.57$ 


\section{Comparison of Latent Structure of Ranking Perception on 'Issues Considered in Media Initial / Brief Meeting' between Ad-Agencies and Clients}

The underlying structure of 'Issues considered in Media Initial / Brief Meeting' is identified based on ranking given by both ad-agencies and clients using principal components method of factor analysis. The analysis shows that ranking scores of both ad-agencies and clients are composed of a single aspect in relation with above measure. The detailed results are presented in the table 1:3. The scree plot is not required for eigenvalues calculated from ranking perception scores of both ad-agencies and clients as they are composed of single aspect each.
Table 1:3 presents the factor loadings of each of the 'Issues considered in Media Initial / Brief Meeting' with extracted factor for both ad-agencies and clients. The table clearly shows that ranking perception of both ad-agencies and clients comprise just one aspect regarding 'Issues considered in Media Initial / Brief Meeting'. The proportion of total variance accounted for by ad-agency factor in their ranking perception score is 88.79 per cent and it is 89.87 per cent for clients

From the overall results presented in the above table, it can be inferred that that the respective ranking perception scores of ad-agencies and clients are falling under one common aspect regarding 'Issues considered in Media Initial / Brief Meeting' and all the items used to measure 'Issues considered in Media Initial / Brief Meeting' forms one collective group with respect to both ad-agencies and clients.

Table 1:3. Factor loadings of 'Issues considered in Media Initial / Brief Meeting' Measurement Items with Extracted Factors for Ad-Agencies and Clients

\begin{tabular}{|c|c|c|c|}
\hline \multirow{2}{*}{$\begin{array}{c}\text { S1 } \\
\text { No }\end{array}$} & Issues considered in Media & \multicolumn{2}{|c|}{ Number of Factors Extracted } \\
\cline { 3 - 4 } & Initial / Brief Meeting & $\begin{array}{c}\text { Cd-agencies } \\
(\mathrm{N}=25)\end{array}$ & \multicolumn{2}{c|}{ Factor } \\
\hline 1 & & Factor & 0.97 \\
\cline { 3 - 4 } & All Objectives & 0.97 & 0.96 \\
\hline 2 & Target Market & 0.98 & 0.98 \\
\hline 3 & Target Audience & 0.94 & 0.94 \\
\hline 4 & Media Budget & 0.94 & 0.98 \\
\hline 5 & Competitors & 0.93 & 0.97 \\
\hline 6 & Media and Its Availability & 0.95 & 0.94 \\
\hline 7 & Product / Brand & 0.97 & 0.84 \\
\hline 8 & Media Buying & 0.84 & 7.1894 \\
\hline & Eigenvalue & 7.1035 & 0.8987 \\
\hline
\end{tabular}

Note: High factor loadings of an item with extracted factors are boldfaced

Table 1:4. Cluster Mean scores of Various Measurement Factors considered by Ad-agencies Regarding 'Media Initial / Brief Meeting' (N=25)

\begin{tabular}{|c|c|c|}
\hline \multirow{2}{*}{ Measurement Items } & \multicolumn{2}{|c|}{ Cluster Means } \\
\cline { 2 - 3 } & $\begin{array}{c}\text { Cluster 1 (N=15) } \\
\text { All Objectives Observant }\end{array}$ & $\begin{array}{c}\text { Cluster 2 (N=10) } \\
\text { Media Budget Observant }\end{array}$ \\
\hline All Objectives & 1.87 & 7.10 \\
\hline Target Market & 3.80 & 5.20 \\
\hline Target Audience & 2.87 & 3.00 \\
\hline Media Budget & 1.20 & 5.60 \\
\hline Competitors & 3.40 & 8.00 \\
\hline Media and Its Availability & 6.47 & 5.00 \\
\hline Product / Brand & 1.87 & 8.00 \\
\hline Media Buying & 6.13 & \\
\hline
\end{tabular}

Source: Primary Data

Note: Scores are in rank. Average rank values below 4 and remarkable difference $(>=1)$ with other cluster group are boldfaced. If difference between cluster means is $<1$ in a row, then both are boldfaced. 


\section{Classification (Grouping) of Ad-Agencies By Their Ranking Perception of Issues Considered in 'Media Initial / Brief Meeting' (26a)}

The mean values of distinct group of ad-agencies classified using cluster analysis based on their ranking perception of "Media Initial / Brief Meeting" are presented in Table 1:4.

From the results presented in the table 1:4, there seems to be that cluster 1 group of ad-agencies are considering all issues except 'Media and its availability' and 'Media buying' with more preference to 'Media budget' followed by 'Product/brand' and 'All objectives' in 'Media Initial / Brief meeting' compared to cluster 2 group of ad-agencies whose consider only 'Media budget' (cluster mean $=3.70$ ) to certain extent. So, in many issues, both cluster groups are having dissimilarity. This strongly envisages the two distinct groups among ad-agencies, one group with 15 ad-agencies considering almost all issues. Hence, on the basis of results obtained, cluster 1 group of ad-agencies is called as 'Observant of All objectives' and cluster 2 group as 'Observant of Media budget'. These groupings are used in cross tabulation with other grouping of ad-agencies to find out association between them.

\section{Sources Media Information / Data}

During the last decade, there have been many changes in advertising media environment. The increasing number of advertising outlets such as specialized magazines, cable channels, television and radio networks, and out of home media make the task of media planners difficult and confusing. An explosion of data for media and markets has accompanied this greater diversity of the media.

These advanced data may elevate some problem faced by the media planners, but the availability of this information may enhance the need for tools to meaningfully interpret and analysis of the raw data. At present, more media planners fight their way out with a number crunching exercises. They calculate reach, frequency (OTS) and efficiency based on syndicated research data and media models which are developed on the basis of the data.

Generally media choice is essentially governed by the quality of media data and quality of analysis of data supplied and made by research agencies and the media planners respectively. In India, there are a number of research studies and models available to the media planners for the effective media planning. Most of the largest ad-agencies' planners are forced to follow some complex methodology for projecting ratings from the available cities to non-represented markets. They are formed to mix estimates from diary and peoplemeter panels, and to mix ratings from viewership panel with universe estimates from the National Readership Survey (NRS) and Indian
Readership Survey(IRS).

Every large advertising medium conducts studies, which delineates its audience by demographic and often socio-psychological characteristics, and it is recognized that the presence of such characteristics may be vital to the purchase or non-purchase of certain products. Further, it brings out the data regarding product use, users and exposure to a specific medium etc. and helps to take decisions. Therefore, many advertising media generate data, in these days, on the subject.

Moreover, the media associations, research organizations in the field of newspapers, magazines, radio, television, outdoor and transportation advertising make similar studies. Admittedly these studies stress the value of the media type rather than individual publication, broadcast stations, or other media firms. Both sources of media information spew forth unbelievably large quantities of material, which must be evaluated by media planners for possible bias.

"The entry of foreign research agencies in India is marking a shift in research standards with the country from simply data collection to industry specific specialisation." 5 The fast increasing media options will necessitate changes in media research efforts. There is also likely to be an increase in demand for relevant market data rather than diagnostic studies.

So, one of the important requisites of a media planner is familiarity with media choice and various sources of media information available The following are the sources of media data available within the media as well as external sources. Based on the following information the clients and ad-agencies can interact during the initial brief meeting.

\section{Findings, Suggestion and Conclusion}

- The use of information to support decision-making on media selection is increasingly recognized by ad-agencies. A well-developed support system for decision making in media planning needs to include data regarding alternative communication formats, market factors, competitors' ad-effort information and objectives.

- In media planning, human judgment in decision-making is a complex phenomena. That is why planners highlight the need to utilize the information held by their clients for effective anticipation, development and creative decision-making.

- The data on the significance of agreement in the ranking perception of information need for media planning reveal the fact that both the media planners and the clients interact sufficiently well regarding the weightage given for initial media plan preparation.

- The results of the Mann-Whitney $U$ test involving a comparison of the rank scores of media planner and their clients regarding information need for media planning clearly highlights the fact that the rank of sum scores of

5. Bharti Rana: Research Gets International, Brand Equity, The Economic Times, 20-26 Sep.1995, p.5. 
planner and clients significantly differ from each other in budget information, competitive ad-effort information, market size information, product/brand information, reach and frequency information, segmentation and target market information.

- In the plan meeting, the planners and the clients decide about ad-budget considering reach, frequency strategies. Non adherence to the ad-budget allocation by clients creates the problem of insufficient reach and frequency determination.

- Many times the ad-agencies and clients representatives not in a position to take immediate decision on media planning due to the limited power given by top authorities. So it is better to participate the person who is having full authority in approving the initial brief meeting reports.
- Sometimes the clients don't want to share the business secrets with ad-agencies during initial brief meeting fearing that it may be misused by ad-agencies. The ad-agencies also accusing clients for not providing sufficient information which lead to poor media planning.

- In some clients representative who participate in the media brief meeting felts that the representatives from ad-agencies who participate in the brief meeting not up to their expectation in terms of professionalism. This leads to clients switch over to another ad-agency after the brief meeting .

- Some clients felt that big media- budgets clients always considered significant in the eyes of ad-agencies others views were neglected or not seriously considered during the brief/initial meeting.

Table 1:5. Sources of Media Information

\begin{tabular}{|c|c|}
\hline Sources & Type of Data Available \\
\hline Population Census & $\begin{array}{l}\text { Total Profile of Indian people (size, strata, age, sex, ratio, literacy level, family } \\
\text { size and forms etc) }\end{array}$ \\
\hline Annual Economic Survey & SEC (Socio - Economic Classification) income, occupation, etc., \\
\hline $\begin{array}{l}\text { India Year Book (Publication division of Ministry of } \\
\text { Information \& Broad casting) }\end{array}$ & $\begin{array}{l}\text { Holistic view of data on various aspects of governance, demographic progress } \\
\text { etc., }\end{array}$ \\
\hline $\begin{array}{l}\text { INFA (Indian News and Feature Alliance Year Book - New } \\
\text { Delhi) }\end{array}$ & Details information on various newspapers, magazines \\
\hline $\begin{array}{l}\text { Audit Bureau of Circulation (ABC) (It is bring out in support of } \\
\text { newspaper publishers, magazine publishers, advertisers, } \\
\text { ad-agencies) }\end{array}$ & Each medium reflected its circulation figures \\
\hline Indian News Paper Society Hand Book (INS) & $\begin{array}{l}\text { It brings out location / headquarters / registered office of publications, no. of } \\
\text { editions, cover price, issue day, circulation key personnel etc., }\end{array}$ \\
\hline $\begin{array}{c}\text { Syndicated Research of } \\
\text { IMRB , MARG, NCAER, NRS, IRS and Other agencies }\end{array}$ & $\begin{array}{l}\text { Syndicated research is often based on a given sample or panel survey, of which } \\
\text { the entire or part is supplied to various users. }\end{array}$ \\
\hline $\begin{array}{l}\text { NRS conducted 1971, 1978, 1983, 1990, 1994, 1995, 1988, } \\
2000\end{array}$ & $\begin{array}{l}\text { It covers estimates for various selected publications, viewership of TV, Video, } \\
\text { Cinema, Listernership ration, duplication between publication and inter media } \\
\text { duplications }\end{array}$ \\
\hline $\begin{array}{l}\text { IRS (Indian Readership Survey) by Media Research Users } \\
\text { Council (MRUC) IRS-95 by ORG }\end{array}$ & Study on Urban / Rural markets, Channel penetration \\
\hline Data Base for Electronic Media & $\begin{array}{c}\text { Doordarshan and All India Radio given data on TV, viewership, etc., - It is } \\
\text { frequently used by the media planners. }\end{array}$ \\
\hline TV India: (Ministry of Information \& Broadcasting) & $\begin{array}{l}\text { Provides information on Estimated television sets, transmission centers, code } \\
\text { for advertising etc., }\end{array}$ \\
\hline Radio Hand Book & $\begin{array}{l}\text { Station / tariff / rules/audience size/ code for commercial advertising AIR } \\
\text { address etc., }\end{array}$ \\
\hline People meter system of IMRB, ORG-MARG, INTAM - TAM & Gives GRP Ratings - Reach / Frequency (OTS) etc., \\
\hline FM & Data on broad casting, young listenership, etc., \\
\hline ORG - Sales Audit & $\begin{array}{l}\text { Data on retail outlets and audit the movements of different products from the } \\
\text { shops itself. }\end{array}$ \\
\hline NCAER : (National Council of Applied Economic Research) & Mapping the markets and consumer perceptions. \\
\hline Data on Competitors' media expenditure & Publishers by News papers, magazines, trade publications, etc., \\
\hline Government and Industry sources & Information provided by FICCI, CII, ASCHOM, SCOPE \\
\hline
\end{tabular}

Source: Secondary Data. 


\section{Conclusion}

In a rapidly changing world, one cannot do business with yesterday's tools. In this context the ad-industry devises new tools to deal with the consumer and the brands. Regarding the advertising strategy, the focal point will be creating advertisements and delivering them through appropriate media, at a lower cost to a larger audience. The modern ad-agencies offer specialized knowledge, skill and experience which are required to implement the effective ad-campaign for their clients. Media planning in ad-agency involves the series of decisions to be made regarding the selection and use of media, allowing the marketers to communicate optimally the message so as to reach the target market at the possible minimum cost. Traditionally, media planning was considered the least important function in ad-agency but it has now become a formidable task because of media explosion, costs, clients' demand in terms of media, impact on consumer and sudden burst of information. Media planners not only select the media for the campaign based on their judgment but they also defend those decision arrived at after considering many alternatives. The proliferation of media options, spiraling ad-cost, the growing number of clients and poor revenue allocation in ad-budget are the important factors, urging for serious media planning and practice. The brief meeting can be considered a checklist and guide for the media planner. The main purpose of conducting brief meeting is to formally evaluate the current state/progress, growth of brands and its market structure in the light of the brand intention of the clients. If there is difference in perception of information sharing by ad-agencies and clients in the initial stage of media planning will dilute the company objectives which is hoping to achieve through media. It always better for the clients to have understanding with ad-agencies in sharing information and consider ad-agencies as partners of their business.

\section{REFERENCES}

[1] Anthonly F. McGann, Thomas Russell J: Advertising Media IRWIN, Homewood Illinois 60430, Second Edition.

[2] Arnold Barban, Stephan M. Cristol and Frank J. Kopec: Essentials of Media Planning, Crain Books, Chicago, 1975. P.1

[3] Barban, Arnold M.Donald, W. Jugenheimer and Lec F. Yound Grid Inc. Columbus Ohio 1975 P.4

[4] Behrmann, William: Putting Effective Frequency to work in Media Planning in Transcript Proceedings: Effective frequency state of the Art, New York, Advertising Research Foundation 1982.

[5] Bharti Rana: Research Gets International, Brand Equity, The Economic Times, 20-26 Sep.1995, p.5.

[6] Bruce G. Varden, Bergh Helen Katz: Advertising Principle, Choices Challenges Change, NTC Business Books,
Lincoinwood Illinois, USA.

[7] Chunawalla S.A and Sethia K.C. Foundations of Advertising Theory and Practice, Himalaya Publishing House, New Delhi, 1999.

[8] Courtlans L. Bovee William F. Arens: Contemporary Advertising, IRWIN Homewood, IL 60430 Boston MA 02116.

[9] 8. Donald Parente: Advertising Campaign Strategy - A guide to marketing communication plans, The Dryden Press Fortwoth,2000.

[10] Farbey, A.D: How to Produce Successful Advertising, Kogan Page Ltd., London, 1994.

[11] George E. Belch, Michael A Belch: Introduction to Advertising and Promotion, IRWIN London.

[12] Geard. J. Tellis: Advertising and Sales Promotion Strategy, Addition - Wesley Inc, Newyork.

[13] Harschell Gordon Lewis, Carol Nelson: Advertising Age, Hand Book of Advertising, NTC Business Books, Illinois 60646- 1975 USA.

[14] Jagadeep Kapur : 24 Brand Mandras, Mandras to work Brand Magic, The Hindu Business Line, 26th April 2001, p.2.

[15] Jaishri N. Jethwaney: Advertising Phonix Publishing House Pvt Ltd., New Delhi - 11001.

[16] Kazmi S.H.H. Satish K. Batra: Advertising and Sales Promotion, Excel Books, New Delhi - 110028, First Edition 2001.

[17] Manendra Mohan: Advertising Management Concepts and Cases, Tata McGraw Hill Publishing Company Ltd., New Delhi 1993.

[18] Martin. P. Davis: The Effective use of Advertising Media, Hutchinson Business, London.

[19] Monidipa Mukherjee: Inspiration Director, Brand Equity, The Economic Times, 25-31 Dec.1996, p.4.

[20] Muhamed: Writing a Marketing Plan, Catalyst, The Hindu Business Line, 5th July 2001, p.4.

[21] PARag Diwan: Advertising Management, A Pentagon Press Publication, First Edition, Deep \& Deep Publication, New Delhi - 110027.

[22] Russell Abratt, Deanna Cowan: Client-Agency Perspectives of Information Needs for Media Planning, Journal of Advertising Research, Nov-Dec.1999, p.37.

[23] Samarkant Kukreja: Cutting through the Clutter, Business Today, 19th Aug.2001, p.49

[24] Sean Brierley : The Advertising Hand Book, Routiledge, Taylor \& Fancis group London and Newyork.

[25] Sheunu Sen : Advertising need not be Trigger for smoker, Catalyst, The Hindu Business Line 22nd Feb.2000, p.iv

[26] Shunu Sen: So, What's the difference? Catalyst, The Hindu Business Line, 9th Sep.1999,p.4

[27] Stewart; David. W and David Furse: Effective Television Advertising, Lescington Ky Dc Heath and Co. 1986. 
[28] Terence A Shimp: Advertising Promotion, The Dryden Press Publishers, Tokyo.

[29] Thomas C O'Gvinn Chris T. Allen, Richard J. Semenik: Advertising, South-Western College Publishing, San Francisco 2nd Edition 2000.
[30] Watson Dunn: Arnold M. Barban : Advertising Its Role in Modern Marketing, The Dryden Press, NewYork.

[31] Wells, Burnett, Moriarty: Advertising Principle and Practice, Prentice Hall International Inc., London. 